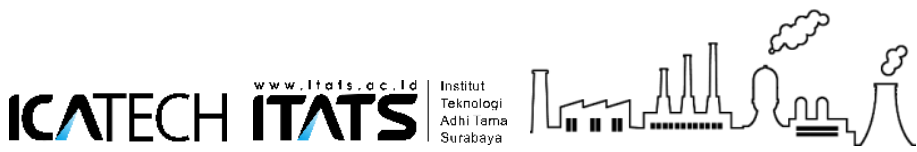

The $1^{\text {st }}$ International Conference on Advanced Engineering and Technology - 2018

\section{Implementation of Kano Methods to Service Quality Improved at PT. Pos Indonesia}

\author{
Suhartini $^{1}$, R Prabowo ${ }^{1}$, N L P Hariastuti ${ }^{1}$ and A D Rafsanjani ${ }^{1}$ \\ ${ }^{1}$ Industrial Engineering Department, Faculty of Industrial Technology, Institut Teknologi Adhi \\ Tama Surabaya, Indonesia \\ suhartini@itats.ac.id
}

\begin{abstract}
PT. Pos Indonesia is a state-owned company engaged in the field of receipt and delivery of goods which was first established in 1746. Frequent problems with freight forwarding services, especially PT. Pos Indonesia is a lack of competitiveness of companies with similar companies, especially private ones. This is because companies are less able to understand the desires and expectations of consumers so that they lose trust and loyalty from consumers. From these problems the purpose of this study was to find a solution using a canoe model in an effort to find improvement proposals to improve quality at PT. Indonesian post. From the research that has been done, there are 4 canoe categories on 11 variables studied. In the category of Must-be, the customer variable is comfortable and strategic location, One Dimensional, namely variable comfortable waiting place, adequate supporting facilities, timely delivery, appropriate price, fast service time and Attractive item security are only professional employee variables, and Indifferent is a lot of service and promotion in various media.
\end{abstract}

\section{Introduction}

In an effort to increase competitiveness in order to obtain trust and loyalty from consumers, PT. Pos Indonesia as a provider of freight and receiving services is required to improve and evaluate the quality of services provided. One strategy that is often used by many companies that focus on the service industry is to improve the quality of service. But it is from this that makes a quality of service said to be a unique phenomenon, because its subjectivity is very high. According to some experts, service quality is a measure of the extent to which a given service can meet customer expectations [1]. While some other experts also mentioned that the quality of service is an expected level of excellence and control over the level of excellence to meet customer desires. With the problems experienced, the purpose of this study was done in the hope of finding a solution in terms of improving the quality of service at PT. Indonesian post. The canoe customer satisfaction model is a useful tool for classifying and prioritizing based on how they affect customer satisfaction [2]. With this Kano concept researchers expect an increase in the quality of service provided by PT. Pos Indonesia based on the expectations and desires of consumers.

\section{Literature Review}

\subsection{Service Quality}

Quality is something that is decided by customers [3]. Service quality is an integral part of consumer satisfaction [4]. Marketing a service quality service depends on the service provider and how to serve 


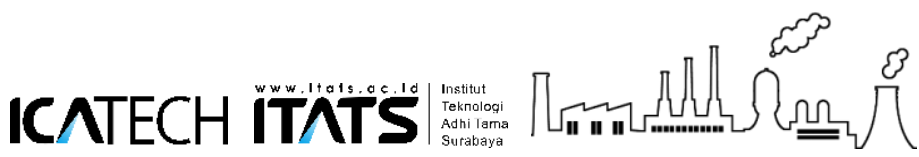

The $1^{\text {st }}$ International Conference on Advanced Engineering and Technology - 2018

[5]. So that the quality image of a service will be a consideration for consumers to choose and buy a product or service. For that, building the image of quality services and products is very important.

Services are activities, benefits, or satisfaction offered for sale [6]. Services are defined as any actions or activities that can be offered by a party to another party, which are basically intangible and do not produce any ownership [7]. Basically, the performance of a service is something that is not intangible even though the application of services often coexists with tangible products [1].

\subsection{Kano Methods}

The consumer satisfaction model of canoeing is a useful tool for classifying and prioritizing based on how they affect customer satisfaction [2]. To find out the pattern of customer satisfaction Dr. Noriaki Kano, who is one of the quality management experts, describes a model that is currently often used to examine customer satisfaction patterns, namely the canoe model. In the process, the canoe method categorizes product or service attributes, based on how well they can satisfy customers [8]. In the application of the canoe method, there are five types of identification categories of attributes used: Must Be or Basic needs. This category is a category that customers rarely pay attention to and the existence of this category will not give more satisfaction to customers. However, if there are deficiencies or unavailability in this category, it will result in dissatisfaction from the consumer. Onedimensional or performance needs. In this category the adequacy and availability of attributes will result in satisfaction and inadequacy and their unavailability will lead to dissatisfaction. Attributes to this category are also known as "better" or "faster better". Attractive attribute or excitement needs. In this category, if the attribute is fulfilled, it will cause an increase in customer satisfaction and the nonfulfillment of this attribute will not disappoint consumers. Indifferent. For this category if an attribute is met or not fulfilled it will not affect customer satisfaction. Reverse. In this category, if an attribute is provided, it will have a decline and vice versa. Questionable. In this category sometimes, an attribute will increase and even reduce customer satisfaction.

\section{Research Methodology}

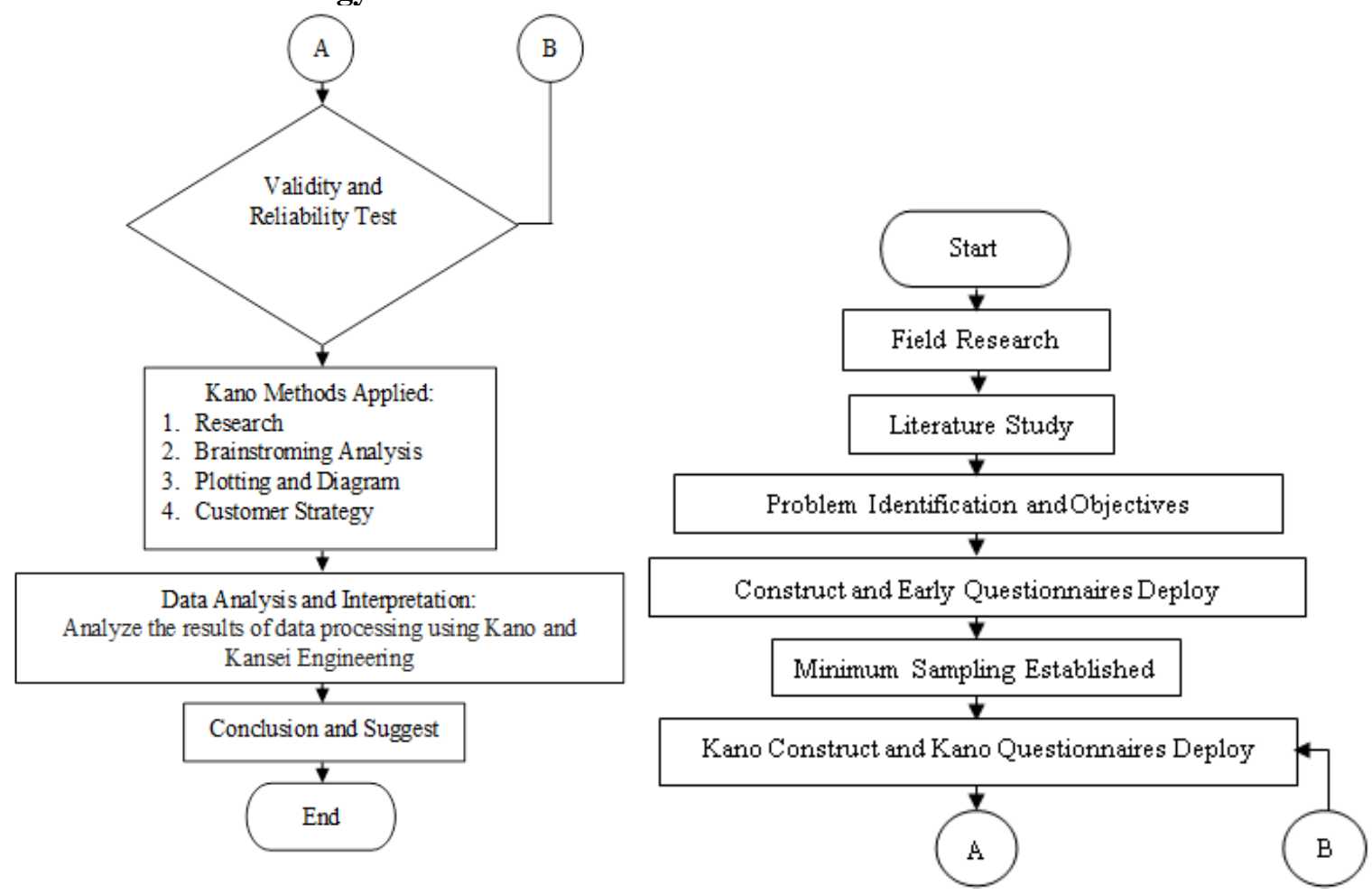

Figure 1. Flowchart of Research Methodology 


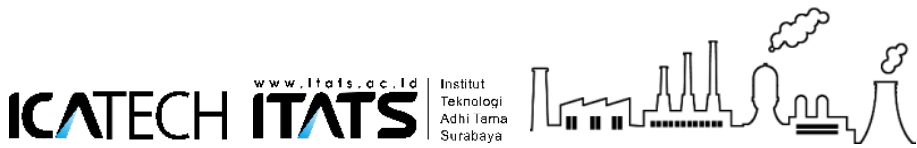

The $1^{\text {st }}$ International Conference on Advanced Engineering and Technology - 201

\subsection{Data Collecting}

3.1.1 Preparation and Distribution of Initial Questionnaire. In an effort to identify, know and understand what the hopes and desires of consumers (the voice of customer) of the service at PT. Pos Indonesia, so that later it will be used as a reference in making improvements to existing services to increase, the initial questionnaire is distributed to 100 respondents who are users of PT. Indonesian post. In distributing the questionnaire, it was found that 42 attributes of consumer desires (voice of customers) of the 42 voice of customer attributes that have been obtained through the open questionnaire will then be grouped based on service dimensions and suitability between attributes.

Table 1. Grouping of Voice of Customer Attributes

\begin{tabular}{|c|c|c|c|c|}
\hline No. & Attribute & Variable & Code & Dimension \\
\hline 1. & Comfortable of Waiting Room & \multirow{3}{*}{$\begin{array}{c}\text { Comfortable } \\
\text { of Waiting } \\
\text { Room }\end{array}$} & \multirow{3}{*}{ T1 } & \multirow{6}{*}{ Tangible } \\
\hline 2. & Adequate Waiting Room Facilities & & & \\
\hline 3. & Clean place & & & \\
\hline 4. & Television added to Make Customers Feel Relax & \multirow{3}{*}{$\begin{array}{c}\text { Adequate } \\
\text { supporting } \\
\text { facilities }\end{array}$} & \multirow{3}{*}{$\mathrm{T} 2$} & \\
\hline 5. & Parking's Indoor has Facilities & & & \\
\hline 6. & Availability of canteen facilities & & & \\
\hline 7. & AC room & \multirow{5}{*}{$\begin{array}{l}\text { The right } \\
\text { price }\end{array}$} & & \\
\hline 8. & A comfortable and well-maintained place of worship & & & \\
\hline 9. & $\begin{array}{l}\text { There is a Queue Number Machine for Tidying the } \\
\text { Queue }\end{array}$ & & & \\
\hline 10. & Goods Until Timely & & R1 & \multirow{10}{*}{ Reliability } \\
\hline 11. & Fast delivery & & K1 & \\
\hline & $\begin{array}{l}\text { Varied Services Like Serving Delivery From Online } \\
\text { Shop }\end{array}$ & \multirow{5}{*}{$\begin{array}{l}\text { Many types } \\
\text { of services }\end{array}$} & \multirow{5}{*}{$\mathrm{R} 2$} & \\
\hline & $\begin{array}{l}\text { Operational Hours Plus To Make It Easy For } \\
\text { Customers }\end{array}$ & & & \\
\hline 14. & $\begin{array}{l}\text { Providing Pickup Services to Make it Easier for } \\
\text { Customers }\end{array}$ & & & \\
\hline 15. & Provides Many Payment Related Ways & & & \\
\hline 16. & Providing Online Services to Be Easy to Access & & & \\
\hline 17. & Costs that are set according & \multirow{3}{*}{$\begin{array}{l}\text { Delivery on } \\
\text { time }\end{array}$} & \multirow{3}{*}{ R3 } & \\
\hline 18. & Low price & & & \\
\hline 19. & Promotional Discounts & & & \\
\hline & Totality employees & \multirow{4}{*}{$\begin{array}{l}\text { Professional } \\
\text { employees }\end{array}$} & \multirow{4}{*}{ Rp1 } & \multirow{7}{*}{ Responsiveness } \\
\hline & Discipline employees & & & \\
\hline 22. & Honest Service & & & \\
\hline 23. & Not Picky in Service and Be Professional & & & \\
\hline & Deft Employees & \multirow{3}{*}{$\begin{array}{l}\text { Fast service } \\
\text { time }\end{array}$} & \multirow{3}{*}{$\mathrm{Rp} 2$} & \\
\hline 25. & Responding Employees & & & \\
\hline & Service is done quickly & & & \\
\hline 27. & Condition of Guaranteed Goods & \multirow{3}{*}{$\begin{array}{l}\text { Goods } \\
\text { security }\end{array}$} & \multirow{3}{*}{ A1 } & \multirow{6}{*}{ Assuranse } \\
\hline & Goods Sent Safely & & & \\
\hline & Goods Tracking Feature Available & & & \\
\hline & Friendly employees & \multirow{3}{*}{$\begin{array}{l}\text { Comfortable } \\
\text { customer }\end{array}$} & \multirow{3}{*}{ A2 } & \\
\hline & Attractive and Polite Employees & & & \\
\hline & Employees Understand of SOP & & & \\
\hline
\end{tabular}




\section{ICATECH ITATS $=\operatorname{Lrmanh} \Omega$}

The $1^{\text {st }}$ International Conference on Advanced Engineering and Technology - 2018

Table 2. Grouping of Voice of Customer Attributes (cont)

\begin{tabular}{|c|c|c|c|c|}
\hline No. & $\begin{array}{c}\text { Attribute } \\
\end{array}$ & Variable & Code & Dimension \\
\hline 33. & The Need for Varying Promotions & \multirow{5}{*}{$\begin{array}{l}\text { Promotion in } \\
\text { various } \\
\text { media }\end{array}$} & \multirow{5}{*}{ E1 } & \multirow{10}{*}{ Emphaty } \\
\hline 34. & $\begin{array}{l}\text { Attractive Promotion Through Online } \\
\text { Media }\end{array}$ & & & \\
\hline 35. & Often Advertise Services on Television & & & \\
\hline 36. & Hold Sponsors in Various Print Media & & & \\
\hline 37. & Designing an Attractive Brochure & & & \\
\hline & $\begin{array}{l}\text { Has a Strategic Location for the } \\
\text { Community }\end{array}$ & \multirow{5}{*}{$\begin{array}{l}\text { Strategic } \\
\text { location }\end{array}$} & \multirow{5}{*}{ E2 } & \\
\hline & Have many branches & & & \\
\hline & Easy Access Location & & & \\
\hline & Even Location & & & \\
\hline & Many are everywhere & & & \\
\hline
\end{tabular}

From the 43 questionnaires that have been obtained then evaluated and recapitulated for each variable based on the canoe evaluation table to determine the response of service users of PT. Pos Indonesia.

Table 3. Data of Variable Identification Results with the Kano Method

\begin{tabular}{|c|c|c|c|c|c|c|c|c|c|}
\hline \multirow{2}{*}{ No. } & \multirow{2}{*}{ Code } & \multirow{2}{*}{ Variable } & \multicolumn{6}{|c|}{ Number of Question } & \multirow{2}{*}{ Total } \\
\hline & & & $\mathrm{O}$ & $\mathrm{A}$ & $\mathrm{M}$ & I & $\mathrm{R}$ & $\mathrm{Q}$ & \\
\hline 1. & T1 & Comfortable waiting area & 19 & 4 & 10 & 9 & 0 & 1 & 43 \\
\hline 2. & $\mathrm{~T} 2$ & Adequate supporting facilities & 11 & 10 & 6 & 16 & 0 & 0 & 43 \\
\hline 3. & R1 & Delivery on time & 19 & 6 & 11 & 6 & 1 & 0 & 43 \\
\hline 4. & R2 & The right price & 12 & 8 & 5 & 18 & 0 & 0 & 43 \\
\hline 5. & R3 & Many types of services & 7 & 5 & 9 & 22 & 0 & 0 & 43 \\
\hline 6. & Rp1 & Professional employees & 7 & 12 & 10 & 14 & 0 & 0 & 43 \\
\hline 7. & Rp2 & Fast service time & 11 & 7 & 9 & 16 & 0 & 0 & 43 \\
\hline 8. & A1 & Goods security & 23 & 6 & 7 & 7 & 0 & 0 & 43 \\
\hline 9. & A2 & Comfortable customer & 9 & 5 & 17 & 12 & 0 & 0 & 43 \\
\hline 10. & E1 & Promotion in various media & 7 & 2 & 4 & 30 & 0 & 0 & 43 \\
\hline 11. & E2 & Strategic location & 6 & 9 & 19 & 9 & 0 & 0 & 43 \\
\hline
\end{tabular}

\subsection{Data Processing}

After disseminating and recapping the results of the questionnaire at the data collection stage, the results of the data recapitulation will then be processed at the data processing stage using the integration of canoeing and Kansei engineering which is then identified to obtain improvement proposals in an effort to improve services at PT. Indonesian post.

\subsection{Data Processing with Kano Methods}

After obtaining the value from the Kano questionnaire for each service quality variable, the next step is to categorize each of these variables into the Kano method. The recapitulation results in table 2 are the first phase of the canoe method, namely recap of functional and dysfunctional questionnaire data.

\section{Result and Discussion}

\subsection{Result Analysis with Kano Methods}

In the analysis phase, the canoe method is used to categorize the eleven variables that have been obtained from the grouping of voice of customers in the open questionnaire into the canoe category. 


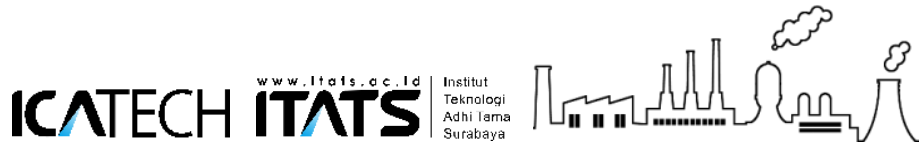

The $1^{\text {st }}$ International Conference on Advanced Engineering and Technology - 2018

The categories include Must-be, One Dimensional, Attractive, Indifferent, Reverse and Questionable. Based on the categorization of each variable using the canoe method, there are 4 categories of canoeing, which are found in 11 existing variables. These four canoe variables include Must-be, One Dimensional, Attractive, and Indifferent. The following is the result of categorizing each variable:

Table 4. Results of Data Processing with Kano Method

\begin{tabular}{|c|c|c|c|c|c|c|c|c|c|c|c|}
\hline \multirow{2}{*}{ No. } & \multirow{2}{*}{ Code } & \multicolumn{6}{|c|}{ Number of Question } & \multirow{2}{*}{ Total } & \multirow{2}{*}{ Category } & \multirow{2}{*}{ Better } & \multirow{2}{*}{ Worse } \\
\hline & & $\mathrm{O}$ & A & $\mathrm{M}$ & $\mathrm{I}$ & $\mathrm{R}$ & $\mathrm{Q}$ & & & & \\
\hline 1. & $\mathrm{~T} 1$ & 19 & 4 & 10 & 9 & 0 & 1 & 43 & $\mathrm{O}$ & 0,55 & 0,69 \\
\hline 2. & $\mathrm{~T} 2$ & 11 & 10 & 6 & 16 & 0 & 0 & 43 & $\mathrm{O}$ & 0,49 & 0,40 \\
\hline 3. & $\mathrm{R} 1$ & 19 & 6 & 11 & 6 & 1 & 0 & 43 & $\mathrm{O}$ & 0,60 & 0,71 \\
\hline 4. & $\mathrm{R} 2$ & 12 & 8 & 5 & 18 & 0 & 0 & 43 & $\mathrm{O}$ & 0,47 & 0,40 \\
\hline 5. & R3 & 7 & 5 & 9 & 22 & 0 & 0 & 43 & I & 0,28 & 0,37 \\
\hline 6. & Rp1 & 7 & 12 & 10 & 14 & 0 & 0 & 43 & $\mathrm{~A}$ & 0,44 & 0,40 \\
\hline 7. & $\mathrm{Rp} 2$ & 11 & 7 & 9 & 16 & 0 & 0 & 43 & $\mathrm{O}$ & 0,42 & 0,47 \\
\hline 8. & A1 & 23 & 6 & 7 & 7 & 0 & 0 & 43 & $\mathrm{O}$ & 0,67 & 0,70 \\
\hline 9. & $\mathrm{~A} 2$ & 9 & 5 & 17 & 12 & 0 & 0 & 43 & $\mathrm{M}$ & 0,33 & 0,60 \\
\hline 10. & E1 & 7 & 2 & 4 & 30 & 0 & 0 & 43 & $\mathrm{I}$ & 0,21 & 0,26 \\
\hline 11. & E2 & 6 & 9 & 19 & 9 & 0 & 0 & 43 & $\mathrm{M}$ & 0,35 & 0,58 \\
\hline
\end{tabular}

Table 5. Results of Must-Be Categorized Variables

\begin{tabular}{cclccc}
\hline No. & Code & \multicolumn{1}{c}{ Variable } & Category & Better & Worse \\
\hline 1. & E2 & Strategic location & $\mathrm{M}$ & 0,35 & 0,58 \\
\hline 2. & A2 & Comfortable customer & $\mathrm{M}$ & 0,33 & 0,60 \\
\hline
\end{tabular}

From the categorization process on customer expectation variables there are 2 variables that are must-be categorized, namely strategic location variables or E2 and Convenient Customer variables or A2. Thus these two variables are the basic variables that must be owned by PT. POS Indonesia which means customers will not be more satisfied if the variable exists but will experience disappointment if the variable does not exist.

Table 6. Results of One Dimensional Category Variables

\begin{tabular}{cclccc}
\hline No. & Code & \multicolumn{1}{c}{ Variable } & Category & Better & Worse \\
\hline 1. & A1 & Goods security & $\mathrm{O}$ & 0,67 & 0,70 \\
\hline 2. & R1 & Delivery on time & $\mathrm{O}$ & 0,60 & 0,71 \\
\hline 3. & T2 & Adequate supporting facilities & $\mathrm{O}$ & 0,49 & 0,40 \\
\hline 4. & R2 & The right price & $\mathrm{O}$ & 0,47 & 0,40 \\
\hline 5. & Rp2 & Fast service time & $\mathrm{O}$ & 0,42 & 0,47 \\
\hline 6. & T1 & Comfortable waiting area & $\mathrm{O}$ & 0,55 & 0,69 \\
\hline
\end{tabular}

Next there are 6 variables categorized as One Dimensional including Comfortable Waiting Places or T1, Adequate Supporting Facilities or T2, Timely Delivery or R1, Appropriate Prices or R2, Fast Service Time or Rp2 and Safety of Goods or A1. Thus the six categories if fulfilled will increase the customer's satisfaction with the service, but if the six attributes are not fulfilled, it will cause excessive disappointment by consumers. 


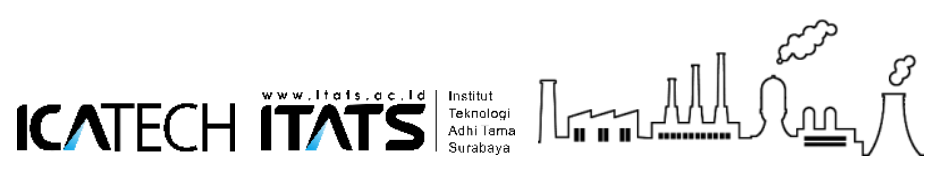

The $1^{\text {st }}$ International Conference on Advanced Engineering and Technology - 2018

Table 7. Results of Attractive Category Variables

\begin{tabular}{cccccc}
\hline No. & Code & Variable & Category & Better & Worse \\
\hline 1. & Rp 1 & Professional Employee & A & 0,44 & 0,40 \\
\hline
\end{tabular}

There is only one variable that is Attractive, namely Professional Employees or Rp1, which means that if PT. Pos Indonesia fulfills this variable so it will increase customer satisfaction but if the variable is not fulfilled then the customer will behave normally.

Table 8. Hasil Variabel Berkatagori Indefferent

\begin{tabular}{cclccc}
\hline No. & Code & Variable & Category & Better & Worse \\
\hline 1. & R3 & Many types of services & I & 0,28 & 0,37 \\
\hline 2. & E1 & Promotion in various media & I & 0,21 & 0,26 \\
\hline
\end{tabular}

Whereas for variables which are categorized as Indifferent, there are two variables, namely Many or R3 Service Type variables and Promotional Variables in Various Media or E1. Thus both the variable fulfilled or not fulfilled will not have any impact on the customer. So that based on the results of the canoe method variables that are categorized as Must-be and One Dimensional need to be prioritized in their fulfillment of other variables.

\section{Conclusion}

From the analysis of the results of research that has been done related to the integration of canoeing and Kansei engineering to improve the quality of service at PT. POS Indonesia, the following conclusions are obtained: The level of importance of the variable variables to the wishes and expectations of customer expectations (customer requirement) of the service of PT. POS Indonesia on canoeing method is as follows there are 4 canoe categories in 11 existing variables. These four canoe variables include Must-be, One Dimensional, Attractive, and Indifferent. Whereas for category acquisition for each variable are 2 Must-be variables, A2 Customer Convenient and variable E2 Strategic Location, One Dimensional 6 variables, T1 Comfortable Waiting Area, Adequate Supporting T2, R1 Timely Delivery, R2 Appropriate Price, Rp2 Fast Service Time and A1 Goods Security, Attractive is only 1 variable, namely the variable Rp1 Professional, and Indifferent as many as 2 variables, namely R3 Type of Service and E1 Promotion in Various Media.

\section{Reference}

[1] R. Prabowo, "New Product Development for Dryer Fish for SMEs Scale with Quality Function Deployment (QFD) Method," in Prosiding International Conference ICOEN 3, 2016.

[2] N. Kano, N. Seraku, F. Takahashi, and S. Tsuji, "Attractive Quality and Must-Be Quality." The Journal of the Japanese Society for Quality Control, vol. 14, no. 2, 1984," J. Japanese Soc. Qual. Control, vol. 14, no. 2, pp. 39-48, 1984.

[3] T. Wijaya, Manajemen Kualitas Jasa. Indeks, 2011.

[4] C. Lovelock and J. Wirtz, People, Technology, Strategy, 7th ed. Pearson Education Inc, 2011.

[5] Kotler and Amstrong, "Principles of Marketing," 2010.

[6] F. Tjiptono and G. Chandra, Service Quality Satisfaction. Andi Offset, 2005.

[7] P. Kotler and K. Keller, Manajemen Pemasaran, Edisi 13, Jilid 1 dan 2. Jakarta: Erlangga, 2009.

[8] A. Shahin and M. Zairi, "Kano Model: A Dynamic Approach for Classifying and Prioritising Requirements of Airline Travellers with Three Case Studies on International Airlines," Total Qual. Manag. Bus. Excell., vol. 20, no. 9, 2009. 